\title{
ENVIRONMENTAL IMPACT FOLLOW UP: A CASE STUDY OF SEVERAL CONSTRUCTION PROJECTS IN VARIOUS UNIVERSITY CAMPUSES
}

\author{
JOSE MORA BARRANTES, GILBERTO PIEDRA-MARIN, JOSE SIBAJA BRENES \& MARIO CORDERO \\ Department of Chemistry, National University, Costa Rica
}

\begin{abstract}
Construction projects have become a driving force for the worldwide economy, with significant impacts on energy consumption, environmental emissions, and social issues. Building constructions and operations have massive, direct and indirect effects on the fragile surroundings. Such adverse impacts include resource depletion, biological diversity losses, landfill problems, decreased productivity, adverse human health, global warming, acid rain, and smog, among others. As a result, many constructors look forward to controlling the adverse impacts of their activities by adopting environmental management systems. Environmental impact assessments (EIAs) are primary instruments for development planning as well as decision making. In a previous work, we carried out the EIAs of seventeen construction projects, to be built in various university campus of Universidad Nacional, Costa Rica. In this work we focused on assessing the significant environmental aspects (SEAs) of eight construction projects, which were completed during 2016-2017, and also on performing social and environmental procedures as a follow-up of the most significant environmental impacts of these eight construction projects. Also, eight procedures related with social and environmental issues were developed in order to perform a follow-up of the most important SEAs identified in our previous work. They were identified thirty three environmental aspects, with 22 of them being classified as significant. The average compliance of the social and environmental procedures for the eight construction projects were in the $77-92 \%$ range, which suggested that these the social and environmental procedures they must be integrated into one general evaluation protocol for assessing every single construction project to be developed.
\end{abstract}

Keywords: Costa Rica, university, environmental aspect, impact assessment, building, construction, social and environmental procedures, checklists.

\section{INTRODUCTION}

The building and construction sectors have significant, worldwide impacts on energy consumption, environmental emissions, and social issues. It has been reported that the building industry generates from $5 \%$ to $15 \%$ of the global GDP (Gross domestic product), and also is responsible for one-third of the total final energy use and half of worldwide electricity consumption, as well as one-third of global carbon emissions [1]-[3]. According to the latest Intergovernmental Panel on Climate Change (IPCC) report [4], [5] the energy use and related emissions associated with building construction and operations may double, or even triple by year 2050, due to population growth, relocation to urban areas, changes in family size, rising levels of affluence, and behavioral changes [5]. Environmental protection measures therefore become an important worldwide issue to be taken into account [2], [6].

Compared to other industries, construction manufacturing is considered an important source of environmental pollution [2], [7]. Building construction and operations have massive direct and indirect effects on the environment [2], [8], since the construction process generates harmful gases, noise, dust, solid and liquid wastes [2], [9]. As a result, many constructors look forward to controlling the adverse impacts of their activities by adopting environmental management systems [2], [10], [11]. The construction of buildings have also some marginal negative impacts, particularly during the crushing process, on the socio- 
economical and biophysical environment such as the degradation of air quality provoked by dust release. Besides, it may provoke loss of habitat for some fauna/flora species and also biodiversity reduction due to vegetation clearing near the extraction site [12], [13]. Construction projects have become a driving force for the worldwide economy, whose energy consumption, environmental emissions, and social impacts are significant [14]-[19]; construction projects also damage the surrounding fragile environments due to the adverse impacts of building erection [14]. Such impacts include resource depletion, biological diversity losses (as a consequence of raw material extraction), landfill problems (due to waste disposal), lower personnel productivity, adverse human health (attributable to poor indoor air quality), global warming, acid rain, and smog release (as a result of emissions generated by building product manufacture) and transport that consumes energy [20]. Enhancing the identification of the major environmental impacts of construction processes will help to improve the effectiveness of environmental management systems. Furthermore, prediction of the correlated environmental impacts of construction before the construction stage, will lead to improvements in the environmental performance of both construction projects and sites. The determination of major environmental impacts will assist to consider a range of on-site measures in order to mitigate them [2], [21].

During the last 20 years, there have been significant developments in the assessment of the environmental impact of building construction. The common tendency has been to establish an objective and comprehensive methodology for assessing a broad range of environmental impacts caused by a building or even a group of buildings. The purpose of these schemes is to measure the environmental sustainability of a built environment in a consistent and comparable manner, with respect to pre-established standards, guidelines, factors, or criteria [22], [23]. The two main approaches that have been used to design environmental assessment schemes for buildings are life cycle assessment (LCA) and building assessment methods (also known as rating systems). In some applications, both of these approaches were combined [22]-[25].

The majority of Latin American countries have acknowledged formal Environmental Impact Assessment (EIA) systems for assessing the significant environmental effects and risks associated with the development of any project being developed [26]. The official national authority evaluates the EIA prepared by the developer and determines whether or not the assessment meets all legal requirements [26], [27]. The immediate aim of an EIA is to inform the process of decision making by identifying the potentially significant environmental effects and risks of development projects. The ultimate (long term) aim of a EIA is to promote sustainable development by ensuring that projects do not undermine critical resource and ecological functions or the wellbeing, lifestyle and livelihood of the communities and people who depend on them [12].

The official national authority in Costa Rica that evaluates EIA is the Environmental National Technical Secretariat (SETENA), a branch of the Environment, Energy and Telecommunications Ministry (MINAET) SETENA employs an electronic assessment outline, called the D-1 form, as a technical evaluation instrument during the first stages of the EIA, so that decision can be made regarding the feasibility of a planned activity, work or project from an environmental point of view, and also to determine if an additional analysis, would be required [26], [28]-[30]. In order to ensure that the proposed mitigation measures (coming from an EIA process) will be carried through, an environmental management plan has to be enforced during all stages of the construction project, so that it is assured the protection of the environment. Such an environmental plan have to specify the nature of the negative impact, the proposed mitigation measures, the indicators in the execution of these 
mitigation measures, the time period, the responsibilities and the follow-up needed from concerned and specified parties. [12].

In a previous work [26], we carried out the EIA of seventeen new construction projects, to be built in various university campus of Universidad Nacional, Costa Rica. In this work we focus on assessing the significant environmental aspects (SEAs) of eight construction projects, which were completed during 2016-2017, by using the SETENA D-1 Form, and also on developing social and environmental procedures as a mean to perform a follow-up of the most significant environmental impacts of these eight construction projects. The environmental and social procedures developed focused onto reducing the potential negative impacts of each project on: natural resources, soil, wildlife, flora, air, human health, water and social-cultural.

\section{METHODOLOGY}

\subsection{Environmental assessment impact}

In order to assess the environmental impacts of the eight building projects, the SETENA D1 form was employed. Such a tool includes several items associated with environmental aspects (EA), assessment criteria (AC) and weighting factors (WF) [26]. With the intention of establishing the weighting factors, they were established eight impact categories (IC), namely, natural resources, soil, wildlife, flora, air, human health, water and social-cultural.

\subsection{Data sources}

The data employed to calculate the different environmental impacts of each project, were obtained from the following sources: (a) Work sessions with architects, civil engineers, mechanic engineers, electric engineers, future-facility users and experts in environmental/ social issues; (b) Public consultation and participation; (c) Studies around the area of each project: biological environment report, soil and geology evaluation report, archaeological and cultural sites report, hydrological and hydrogeological studies, natural and anthropogenic threats, social-economic and cultural studies, physical environment report; (d) Architectonic design, water and energy consumption estimation; (e) Official documents from Costa Rican Statistical Information Service (INEC), National Institute of Environmental Research (MINAET), Ministry of Public Health (MPH), Public Universities Information Centers; and (f) Site inspections.

\subsection{Social and environmental management procedures}

Some negative impacts of the projects may be eliminated, reduced or compensated if the proposed environmental management procedures are followed as agreed. In order to control and maintain a good environmental management during the entire construction project, several procedures were implemented during the construction stage. Such procedures resulted from several working sessions (from year 2012-2014) with social and environmental management officers from Costa Rican public universities. These control procedures were applied in the 8 construction projects developed in Universidad National (UNA). To evaluate the compliance of the procedures, eight check lists were developed. The main goal of each check list was to assure that every action included in the social and environmental procedures are applied by the construction company staff at all construction stages. University officers, along with the construction personnel, verified on a weekly basis (by using the check lists) the application of the different elements (actions) described in the social/environmental 
procedures. In-situ check lists were used to confirm the achievement of good practices performed by the constructors. The monitoring took place throughout the project life cycle; that is to say, from the very start date until completion of the project and acceptance by the university authorities.

\section{RESULTS AND DISCUSSION}

Table 1 summarizes the construction areas, footprint constructions, number of floors and planned uses of the eight building projects chosen for this study. The construction areas lied in the 900.00-11150.00 $\mathrm{m}^{2}$ range. The majority of buildings $(\mathrm{n}=5)$ did not exceed 3 floors; however, projects $\mathrm{E}$ and $\mathrm{F}$ are four and six-story facilities, being project $\mathrm{F}$ the tallest of all (six floors). Project $\mathrm{H}$ spans the largest construction area $\left(11150.00 \mathrm{~m}^{2}\right)$. Half $(\mathrm{n}=4)$ of these buildings are addressed to be used in administrative and teaching activities. However, some facilities were designed to hold special uses; for example, project F contains 23 chemistryrelated laboratories (analytical, organic, biochemistry, water and soil quality, atmospheric pollution, pesticides and so on), chemical products/wastes warehouses, and a small-scale industrial plant. Project $\mathrm{G}$ will bear laboratories and equipment designed to work with radioactive materials. Projects $\mathrm{A}, \mathrm{B}, \mathrm{C}$ and $\mathrm{D}$ will be utilized as student dormitories; they have similar structure as well as inputs and outputs, although they vary in the number of rooms. These dormitory projects have construction areas that fall in the $900.00-3650.00 \mathrm{~m}^{2}$ range.

Table 2 lists the environmental aspects evaluated for all eight building projects. The environmental aspects classified as SEA are indicated with an asterisk symbol (*). For every project, they were evaluated thirty three EAs, in accordance with the Assessment Criteria

Table 1: Construction areas, footprint constructions, floors and description of the eight building projects.

\begin{tabular}{|c|c|c|c|c|}
\hline PL & $\mathrm{CA}\left(\mathrm{m}^{2}\right)$ & $\mathrm{FP}\left(\mathrm{m}^{2}\right)$ & $\mathrm{F}$ & Description (planned uses) \\
\hline A & 900.00 & 450.00 & 2 & \multirow{4}{*}{ Student dormitories sports facilities. } \\
\hline B & 3078.00 & 1803.00 & 3 & \\
\hline $\mathrm{C}$ & 2200.00 & 1575.00 & 1 & \\
\hline $\mathrm{D}$ & 3650.00 & 1650.00 & 1 & \\
\hline $\mathrm{E}$ & 4500.00 & 2350.00 & 4 & Areas for administrative work. \\
\hline $\mathrm{F}$ & 6000.00 & 1200.00 & 6 & $\begin{array}{l}\text { Areas for academic, teaching and } \\
\text { administrative duties. }\end{array}$ \\
\hline $\mathrm{G}$ & 3000.00 & 1000.00 & 3 & $\begin{array}{l}\text { Areas for academic, teaching and } \\
\text { administrative activities. Chemical and } \\
\text { physical labs, dangerous goods warehouse, } \\
\text { small scale industrial plant. }\end{array}$ \\
\hline $\mathrm{H}$ & 11150.00 & 7000.00 & 3 & $\begin{array}{l}\text { Includes: classrooms, library, meeting } \\
\text { rooms, sport facilities, auditorium and } \\
\text { areas for academic, teaching and } \\
\text { administrative activities. }\end{array}$ \\
\hline Total & 34478.00 & 21078 & 24 & \\
\hline
\end{tabular}

PL: Project Label; CA: Construction Area; FP: Foot Print; F: Floors. 
Table 2: Significant environmental aspects identified for the eight projects evaluated.

\begin{tabular}{|c|c|c|c|c|c|c|c|c|}
\hline \multirow{2}{*}{ Environmental aspects } & \multicolumn{8}{|c|}{ Projects } \\
\hline & $\mathbf{A}$ & $\mathbf{B}$ & $\mathbf{C}$ & $\mathbf{D}$ & $\mathbf{E}$ & $\mathbf{F}$ & $\mathbf{G}$ & $\mathbf{H}$ \\
\hline Water consumption (WC) & $*$ & & $*$ & $*$ & $*$ & $*$ & $*$ & $*$ \\
\hline Energy consumption (EC) & $*$ & & $*$ & $*$ & $*$ & $*$ & $*$ & \\
\hline \multicolumn{9}{|l|}{ Fossil fuel usage (FF) } \\
\hline \multicolumn{9}{|l|}{ Soil modification (SMd) } \\
\hline \multicolumn{9}{|l|}{ Surface runoff increase (SR) } \\
\hline Treatment and disposal of ordinary waste (OW) & $*$ & $*$ & $*$ & $*$ & $*$ & $*$ & $*$ & $*$ \\
\hline Treatment and disposal of special waste (SW) & & & & & & $*$ & $*$ & \\
\hline Treatment and disposal of debris building (DB) & $*$ & $*$ & $*$ & $*$ & $*$ & $*$ & $*$ & $*$ \\
\hline Treatment and disposal of chemical waste $(\mathrm{CW})$ & & & & & & $*$ & $*$ & \\
\hline Treatment and disposal of radioactive waste (RW) & & & & & & & $*$ & \\
\hline Treatment and disposal of biological waste (BW) & & & & & & $*$ & & \\
\hline Soil/land movement (S) & & & & & & $*$ & $*$ & \\
\hline Slope land modification (SM) & & & & & & $*$ & & \\
\hline \multicolumn{9}{|l|}{ Building Density (BD) } \\
\hline \multicolumn{9}{|l|}{ Wildlife Affectation (WA) } \\
\hline Deforestation (DF) & & $*$ & * & * & $*$ & & & \\
\hline Emissions from stationary sources (SS) & & & & & & $*$ & & \\
\hline Emissions from mobile sources (MS) & $*$ & $*$ & $*$ & $*$ & $*$ & $*$ & $*$ & $*$ \\
\hline Odor generation $(\mathrm{OG})$ & * & $*$ & * & $*$ & $*$ & $*$ & $*$ & $*$ \\
\hline \multicolumn{9}{|l|}{ Ionizing radiation emissions (RE) } \\
\hline Production of noise and vibration (NV) & $*$ & $*$ & $*$ & $*$ & $*$ & $*$ & $*$ & $*$ \\
\hline \multicolumn{9}{|l|}{ Agrochemicals Usage (A) } \\
\hline Use of dangerous goods (DG) & & & & & & $*$ & $*$ & \\
\hline Use of radioactive materials (RM) & & & & & & & $*$ & \\
\hline Use of biological materials (BM) & & & & & & $*$ & & \\
\hline Production of ordinary wastewater (POW) & & $*$ & $*$ & & & & & \\
\hline \multicolumn{9}{|l|}{ Production of special wastewater (PSW) } \\
\hline Population density (PD) & $*$ & & * & * & $*$ & $*$ & $*$ & $*$ \\
\hline Employment generation (EG) & $*$ & $*$ & $*$ & $*$ & $*$ & $*$ & $*$ & $*$ \\
\hline \multicolumn{9}{|l|}{ People relocation (PR) } \\
\hline Landscape alteration (LA) & $*$ & $*$ & $*$ & $*$ & $*$ & & & \\
\hline \multicolumn{9}{|l|}{ Heritage affectation (HA) } \\
\hline $\mathrm{Q}$ & 12 & 10 & 13 & 11 & 11 & \begin{tabular}{|l|}
18 \\
\end{tabular} & 17 & 9 \\
\hline$\%$ & 36 & 30 & 39 & 33 & 33 & 55 & 52 & 27 \\
\hline
\end{tabular}


previously established [26]. Twenty two EAs (66.67\%) showed IEI $I_{\mathrm{EA}}$ outcomes greater than 6 points, and hence they were classified as SEA. Conversely, eleven environmental aspects $(33.33 \%)$ showed $\mathrm{AEI}_{\mathrm{EA}}$ values below 6 points, and therefore were classified as nonsignificant.

According to Table 2, some environmental aspects were classified as SEA in all eight projects, namely: treatment and disposal of ordinary wastes, treatment and disposal of debris building, emissions from mobile sources, production of noise and vibration, population density and employment generation. As a result, special attention must be given to these environmental aspects. For these SEAs a series of procedures were developed and applied during the construction project periods (2016-2017) in order to manage their negative environmental impact.

Table 3 shows the procedures employed to follow up the measures established for diminishing the potential impacts associated with the significant environmental aspects (SEA in all eight projects). According to Table 3, a particular procedure could be used to control various significant environmental aspects simultaneously; for example, the procedure named

Table 3: Social and environmental check lists used to control the potential negative impact of construction projects.

\begin{tabular}{|l|l|}
\hline Procedure (Acronym) & Significant environmental aspect followed up \\
\hline $\begin{array}{l}\text { Local community communication } \\
\text { and conflict resolution procedure } \\
\text { (LCCRP) }\end{array}$ & $\begin{array}{l}\text { Treatment and disposal of debris building, Building } \\
\text { density, Emissions from mobile sources, Odor } \\
\text { generation, Production of noise and vibration, } \\
\text { Employment generation, Population density }\end{array}$ \\
\hline $\begin{array}{l}\text { Solid and liquid waste (hazardous } \\
\text { and ordinary) management } \\
\text { procedure. (SLWP) }\end{array}$ & $\begin{array}{l}\text { Treatment and disposal of ordinary waste, } \\
\text { Treatment and disposal of special waste, Treatment } \\
\text { and disposal of debris building, Treatment and } \\
\text { disposal of chemical waste, Treatment and disposal } \\
\text { of radioactive waste, Treatment and disposal of } \\
\text { biological waste }\end{array}$ \\
\hline $\begin{array}{l}\text { Noise reduction and control and } \\
\text { air pollution procedure (NRAP) }\end{array}$ & $\begin{array}{l}\text { Emissions from mobile sources, Odor generation, } \\
\text { Production of noise and vibration }\end{array}$ \\
\hline $\begin{array}{l}\text { Wastewater management } \\
\text { procedure (WMP) }\end{array}$ & $\begin{array}{l}\text { Water consumption, Surface runoff increase, } \\
\text { Production of ordinary wastewater, Production of } \\
\text { special wastewater }\end{array}$ \\
\hline Construction procedure (CP) & Soil/land movement \\
\hline $\begin{array}{l}\text { Environmental and cultural } \\
\text { restoration procedure (ECRP) }\end{array}$ & $\begin{array}{l}\text { Soil modification, Soil/land movement, Building } \\
\text { density, Deforestation }\end{array}$ \\
\hline $\begin{array}{l}\text { Occupational health procedure } \\
\text { (OHP) }\end{array}$ & $\begin{array}{l}\text { Treatment and disposal of chemical waste, } \\
\text { Treatment and disposal of radioactive waste, Use of } \\
\text { dangerous goods }\end{array}$ \\
\hline $\begin{array}{l}\text { Procedure for the control of } \\
\text { emergency situations (PCES) }\end{array}$ & $\begin{array}{l}\text { Treatment and disposal of chemical waste, } \\
\text { Treatment and disposal of radioactive waste, } \\
\text { Treatment and disposal of biological waste, Use of } \\
\text { dangerous goods, Traffic generation vehicles }\end{array}$ \\
\hline
\end{tabular}


"Communication and conflict resolution procedure" (LCCRP) was applied to verify SEAs such as production of noise and vibration, employment generation, population density, people relocation and traffic generation vehicles. This check list allowed the monitoring of ten environmental aspects.

Tables 4-9 show a summary of the goals and the actions inspected according to the 8 check lists listed in Table 3 . Such check lists allow a good management for the significant environmental aspects detected from de SETENA D-1 Form.

Check lists described in Tables 4-9 were employed to look at the procedures performed by the construction companies contracted for developing the construction projects during years 2016-2017. Table 10 shows the absolute frequencies of application of those check lists in evaluating the procedures. Seven out of eight projects had more than 12 months of operation; the only exception was project A (less than 8 months), and it is therefore the one that shows less frequency data. A grand total of 1115 inspections were carried out during years 2016-2017.

Table 4: Communication and conflict resolution check list.

Procedure: Local community communication and conflict resolution procedure

Check list (Elements): (a) Was the local community informed, about all constructive activities to be carried out, prior to the beginning of works? (b) Are there informative workshops held monthly with the nearest community? (c) Is the local community informed about the interruption of basic services such as supply of drinking water and electric power, public transportation stops and parking lots, communication networks, among others? (d) Are there state building permits properly installed and clearly visible? (e) Is it properly installed and clearly visible the contact information of the construction company? (f) Are there mailboxes available for the local community to make suggestions? (g) Is there an adequate mechanism for resolving conflicts?

Table 5: Solid and liquid waste (hazardous and ordinary) management check list.

Procedure: Solid and liquid waste (hazardous and ordinary) management procedure

Check list (Elements): (a) Are all wastes classified and labeled according to their level of danger? (b) Are all wastes (hazardous, ordinaries, debris building, recyclable) located in the respective collection centers? (c) Are all wastes stored in suitable drums and with individual covers? (d) Are all waste storage areas properly labeled according to the type of waste stored? (e) Are there any wastes stored nearby slopes, river channels, water sources, among others? (f) Are all waste collection centers in good working conditions? (g) Are all wastes stored avoiding direct contact with the ground? (h) Are all wastes stored in the collection center protected from direct contact with rain? (i) Are wastes such as metal, glass, electrical material, and paper, among others, recycled or reutilized? (j) Is there a monthly control of all kinds of waste, either generated or treated? (k) Are wastes transported outside the construction area on authorized vehicles? (l) Are final waste-treatment and waste disposal carried out in authorized places by approved companies? 
Table 6: Reduction and control of noise and air pollution check list.

Procedure: Noise reduction and control and air pollution procedure

Check list (Elements): (a) Are there measures implemented to minimize noise from equipment and heavy machinery? (b) Are the schedules and frequency of use of heavy machinery properly communicated to the local community? (c) Is the heavy-machinery traffic within the construction area maintained at a speed below $20 \mathrm{~km} / \mathrm{h}$ ? (d) Are all construction workers and staff provided with hearing protection equipment? (e) Are there mechanisms available for attenuating noise? (f) Are there mechanisms available to prevent the dispersion of dust outside the construction area? (g) Is there a noise measurement plan? (h) Is there a frequently-measurement parameters list (Suspended Particulate Matter (SPM), Respirable Suspended Particulate Matter (RSPM), Sulphur dioxide $\left(\mathrm{SO}_{2}\right)$, Oxides of Nitrogen $\left(\mathrm{NO}_{\mathrm{x}}\right)$, and Carbon Monoxide (CO))? (i) Do noise levels comply with the national regulations? (j) Are all dump trucks properly covered to avoid releasing material upon transporting? (k) Are all dump-truck wheels cleaned before leaving the construction area? (1) Do all authorized vehicles have the respective permits to move inside and outside the project? $(\mathrm{m})$ Are all potential dust-generation materials (or wastes) adequately covered? (n) Is there a safety perimeter enclosure, made in areas where excavations or demolitions are carried out, in order to avoid dust dispersion?

Table 7: Wastewater management check list.

Procedure: Wastewater management procedure

Check list (Elements): (a) Are there available sanitary cabins in adequate conditions? (b) Is sewage disposed exclusively in sites designed for this purpose, for example, in public sewers and / or sewer treatment plant? (c) Are black sewage separated from gray sewage? (d) Are all wastewaters connected to an authorized sewer treatment system? (e) Is there a properly conditioned site for washing vehicles, equipment and heavy duty machinery? (f) Are there systems used for the retention of sediments, cement particles, among others, to prevent their discharge into the sewage water treatment system or bodies of water? $(\mathrm{g})$ Are there conditioned places to wash out cement-contaminated materials? (i) Is there a frequent monitoring of physical-chemical parameters, nearby public sewage systems? (j) Is there a frequent monitoring of physical-chemical parameters, before and after the sewer treatment plant? $(\mathrm{k})$ Is there a frequent monitoring of physical-chemical parameters of nearby water bodies? (1) Do all physical-chemical parameters comply with the national regulations?

Fig. 1 shows the percentage distribution of compliance with the procedures evaluated for the eight projects evaluated during years 2016-2017. In general, regarding the control and monitoring of the majority of procedures applied, a positive compliance (over 70\%) was observed for all construction projects. LCCRP and ECRP procedures were the ones that showed a better compliance in most of the building projects, with average compliances of $92 \%$ and $94 \%$, respectively (Table 11 ). Project A showed a $62 \%$ compliance regarding procedure LCCRP; such a project was the first one to start off (July, 2016), but it was abandoned twice by two different companies. Project B, for its part, has a construction 
Table 8: Construction check list.

Procedure: Construction procedure

Check list (Elements): (a) Are the following construction sites within the project area duly identified and installed: workshops, equipment storage, dining rooms, camps, concrete preparation site, diesel plant, waste collection sites? (b) Are the following construction sites within the project area duly identified and installed: sanitary cabins, showers, changing rooms? (c) Are the following construction sites within the project area duly identified and installed: safety equipment and materials, First Aid room, firefighting equipment, meeting point, emergency routes and exits? (d) Are the following construction sites within the project area duly identified and installed: Area to store debris, Spill containment area, Area for washing machinery, Area for washing material contaminated with cement? (e) Are all the sites where liquid wastes are stored waterproofed? (f) Are all the sites where liquid products are stored (oils, fuels, paints) waterproofed?

Table 9: Environmental and cultural restoration check list.

Procedure: Environmental and cultural restoration procedure

Check list (Elements): (a) Are there barriers installed to prevent runoff of sediment into natural drainages? (b) Is water spray applied on dirt roads to reduce wind-generated erosion? (c) Are materials, debris or wastes disposed or stored in protective areas and on slopes? (d) Are materials, general wastes or debris stored in the trees perimeters? (e) Are construction residues mixed with the soil's organic layer that was removed during excavations? (f) Are there adequate measures intended to control erosion and sediment runoff to nearby water bodies? (g) Is it used the removed soil's organic layer in the process of revegetation to improve landscape, slopes stabilization and/or maintaining vegetation growth? (h) Is there a professional in archaeological findings and cultural resources as a member of the construction staff? (i) Is there any knowledge regarding the government procedure to be followed in case of archaeological evidence and cultural resources finding? (j) Are all the respective state permits for felling of trees processed? (k) Are natural habitats affected? (l) Is hunting or capture of flora and fauna species prohibited inside and nearby the project? $(\mathrm{m})$ Are green areas affected by the construction project been restored? (n) Has wood of endangered or endemic species been used?

Table 10: Absolute frequencies of application of the check lists in evaluating the procedures applied in the construction projects during 2016-2017.

\begin{tabular}{|l|c|c|c|c|c|c|c|c|}
\hline \multirow{2}{*}{ Procedure } & \multicolumn{10}{|c|}{ Project } \\
\cline { 2 - 9 } & A & B & C & D & E & F & G & H \\
\hline LCCRP & 8 & 18 & 21 & 17 & 20 & 20 & 15 & 20 \\
\hline SLWP & 8 & 18 & 21 & 17 & 20 & 20 & 15 & 20 \\
\hline NRAP & 8 & 18 & 21 & 17 & 20 & 20 & 15 & 20 \\
\hline WMP & 8 & 19 & 21 & 17 & 20 & 20 & 15 & 20 \\
\hline CP & 8 & 18 & 21 & 17 & 20 & 20 & 15 & 20 \\
\hline ECRP & 8 & 18 & 21 & 17 & 20 & 20 & 15 & 20 \\
\hline OHP & 8 & 19 & 21 & 17 & 20 & 20 & 15 & 20 \\
\hline PCES & 8 & 19 & 21 & 17 & 20 & 20 & 15 & 20 \\
\hline TOTAL & 64 & 147 & 168 & 136 & 160 & 160 & 120 & 160 \\
\hline
\end{tabular}




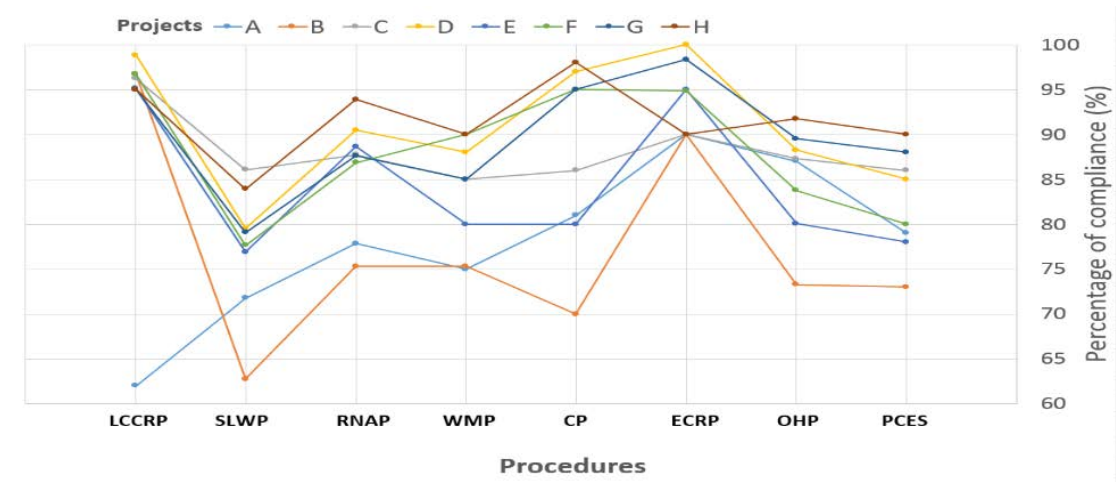

Figure 1: Percentage distribution of compliance for the social and environmental procedures applied during construction projects.

Table 11: Average of compliance for each procedure (\%) in every infrastructure project.

\begin{tabular}{|l|c|c|c|c|c|c|c|c|c|}
\hline \multirow{3}{*}{ Procedure } & \multicolumn{10}{|c|}{ Average of compliance for each procedure (\%) } \\
\cline { 2 - 11 } & \multicolumn{1}{|c|}{ A } & B & C & D & E & F & G & H & General average \\
\cline { 2 - 10 } LCCRP & 62 & 97 & 96 & 99 & 95 & 97 & 95 & 95 & $\mathbf{9 2}$ \\
\hline SLWP & 72 & 63 & 86 & 80 & 77 & 78 & 79 & 84 & $\mathbf{7 7}$ \\
\hline NRAP & 78 & 75 & 88 & 90 & 89 & 87 & 88 & 94 & $\mathbf{8 6}$ \\
\hline WMP & 75 & 75 & 85 & 88 & 80 & 90 & 85 & 90 & $\mathbf{8 4}$ \\
\hline CP & 81 & 70 & 86 & 97 & 80 & 95 & 95 & 98 & $\mathbf{8 8}$ \\
\hline ECRP & 90 & 90 & 90 & 100 & 95 & 95 & 98 & 90 & $\mathbf{9 4}$ \\
\hline OHP & 87 & 73 & 87 & 88 & 80 & 84 & 90 & 92 & $\mathbf{8 5}$ \\
\hline PCES & 79 & 73 & 86 & 85 & 78 & 80 & 88 & 90 & $\mathbf{8 2}$ \\
\hline General average & $\mathbf{7 8}$ & $\mathbf{7 7}$ & $\mathbf{8 8}$ & $\mathbf{9 1}$ & $\mathbf{8 4}$ & $\mathbf{8 8}$ & $\mathbf{9 0}$ & $\mathbf{9 2}$ & - \\
\hline
\end{tabular}

progress above $70 \%$; however, the construction company in charge of this infrastructure experienced financial difficulties that limited progress of the works,. Hence, projects A and $\mathrm{B}$ are the ones that showed a lower performance in the fulfillment of all the environmental and social procedures.

Procedure SLWP showed a wide compliance percent variation, in the $63-86 \%$ range. Such variability is mainly due to the unavailability of adequate sites for waste accumulation and disposal; for instance, in some infrastructure projects wastes were disposed directly onto the ground and were not protected from the rain either. In addition, SLWP procedure showed the lowest average compliance percentage overall $(72 \%)$. Conversely, the ECRP procedure showed the highest average compliance percentage (94\%), Fig. 1 shows compliance percentages equal or greater than $90 \%$ for all eight projects. It should be noted that 5 out of the (A, B, C, D, E and $\mathrm{H})$ of the 8 projects, previous to the start of the construction operations, required felling and cutting of trees; all governmental permits were duly processed in advance, and also all these projects have a reforestation plan intended to recover the areas significantly affected.

In general, it may be assured that procedures NRAP and WMP showed good control and monitoring by both the construction company staff and by the university's inspection staff. 
Six out of eight construction projects showed a percentage of compliance equal to or greater than $85 \%$. Among the most important actions applied to comply with the requirements included in these procedures are; installation of barriers for dust and noise, periodic measurements of parameters such as particulate matter, noise and vibration. To protect water resources, a periodic control on water bodies and wastewater treatment systems were carried out. The following physical and chemical parameters were monitored periodically color, odor, $\mathrm{pH}$, electrical conductivity, total dissolved substances, turbidity, total hardness, of chemical oxygen demand (COD), biological oxygen demand (BOD) total suspended solids (TSSs), total nitrogen (TN), total phosphorous (TP), among others.

\section{CONCLUSION}

A total of eight procedures related with social and environmental matters were developed in order to follow up the most important significant environmental aspects (treatment and disposal of ordinary wastes, treatment and disposal of debris building, emissions from mobile sources, production of noise and vibration, population density and employment generation), and hence they must be integrated into one general evaluation protocol for assessing every single construction project to be developed.

Eight check lists were applied (2016-2017) by university staff together with the construction company personnel in order to guarantee a low environmental impact, into the eight environmental sectors evaluated in the D-1 SETENA Form (Natural resources, Soil, Wildlife, Flora, Air, Human Health, Water and Social-Cultural) during this investigation. A grand total of 1,115 inspections were carried out.

In general terms, a positive compliance (over 70\%), regarding the control and monitoring for most of the social and environmental procedures, was evidenced in all construction projects. The procedures named "Local community communication and conflict resolution procedure" (LCCRP) and "Environmental and cultural restoration procedure" (ECRP) were the ones that showed a better compliance for most of the projects, with average compliance percentages of $92 \%$ and $94 \%$, respectively.

"Solid and liquid waste (hazardous and ordinary) management procedure" (SLWP) showed the lowest average compliance percentage (72\%), due to some difficulties associated with the disposal of solid wastes. On the contrary, the "Environmental and cultural restoration procedure" (ECRP) had an average percentage of compliance of $94 \%$. This procedure showed an compliance percentage equal or greater than $90 \%$ for all the projects.

Among the actions developed by the construction companies to protect the environment and the social environment were: follow up of to the information include in the suggestion boxes, periodic meetings with the local community, systems for the control of dust and noise, protection of river banks, protection of trees within and outside the project area, protection of water bodies and wastewater treatment systems, monitoring of air and water quality.

The present research showed that a good planning prior to the start off of any construction project (including the monitoring and control of environmental and social aspects), provide both the developer and the construction company with useful tools to ensure a good environmental and social performance during all stages of the project, specially to follow up the significant environmental aspects detect in the D-1 SETENA Form.

\section{REFERENCES}

[1] Selvacumar, S. \& Jeykumar, R.K.C., Environmental impact assessment for building construction projects. International Journal of Computational Sciences and Information Technology, 1(1), pp. 29-40, 2015. 
[2] Zolfagharian, S., Nourbakhsh, M., Irizarry, J., Ressang, A. \& Gheisari, M., Environmental impacts assessment on construction sites. Construction Research Congress 2012, 2012.

[3] Lam, P.T.I., Chan, E.H.W., Chau, C.K., Poon, C.S. \& Chun K.P., Environmental management system vs green specifications: How do they complement each? 2011.

[4] Intergovernmental Panel on Climate Change (IPCC), Managing the Risks of Extreme Events and Disasters to Advance Climate Change Adaptation; Field, eds C.B. Barros et al., Cambridge University Press: Cambridge, New York, 2012.

[5] Emami, N., Marteinsson, B. \& Heinonen, J., Environmental impact assessment of a school building in Iceland using LCA-including the effect of long distance transport of materials. Buildings, 6(4), p. 46, 2016. DOI: 10.3390/buildings6040046.

[6] Tse, Y. \& Raymond, V., The implementation of EMS in construction firms: Case study in Hong Kong. Journal of Environmental Assessment Policy and Management, 3, pp. 94-177, 2001.

[7] Shen, L.-Y., Lu, W.-S., Yao, H. \& Wu, D.-H., A computer-based scoring method for measuring the environmental performance of construction activities. Automation in Construction, 14(3), pp. 297-309, 2005. DOI: 10.1016/j.autcon.2004.08.017.

[8] Levin, H., Systematic Evaluation and Assessment of Building Environmental Performance (SEABEP). Paper for pr\$esentation to Buildings and Environment, Paris, 9-12 Jun. 1997.

[9] Chen, Z., Li, H. \& Wong, C.T.C., Environmental management of urban construction projects in China. Journal of Construction Engineering and Management, 126, pp. 320-324, 2000. DOI: 10.1061/(asce)0733-9364(2000)126:4(320).

[10] Lam, P.T.I., Chan, E.H.W., Chau, C.K., Poon, C.S. \& Chun K.P., Environmental management system vs green specifications: How do they complement each other in the construction industry? Journal of Environmental Management, 92, pp. 788-795, 2011.

[11] Shen, L.-Y., Lu, W.-S., Yao, H. \& Wu, D.-H., A computer-based scoring method for measuring the environmental performance of construction activities. Automation in Construction, 14, pp. 297-309, 2005.

[12] Rwanda Stones \& Construction (RSC) Ltd Co., Environmental impact assessment (EIA) report for a stone crushing factory, 2011. www.miga.org/documents/ EIA_Rwanda_Stones.pdf.

[13] Li, X., Zhu, Y. \& Zhang, Z., An LCA-based environmental impact assessment model for construction processes. Building and Environment, 45(3), pp. 766-775, 2010.

[14] Enshassi, A., Kochendoerfer, B. \& Rizq, E., An evaluation of environmental impacts of construction Projects. Revista Ingeniería de Construcción RIC, 29, N3, 2014. www.ricuc.cl.

[15] Morledge, R. \& Jackson, F., Reducing environmental pollution caused by construction plant. Environmental Management and Health, 12(2), pp. 191-206, 2001.

[16] Ball, J., Can ISO 14000 and eco-labelling turn the construction industry green? Building and Environment, 37(4), pp. 421-428, 2002.

[17] Chen, Z., Li, H. \& Hong J., An integrative methodology for environmental management in construction. Automation in Construction, 13(5), pp. 621-628, 2004.

[18] Zolfagharian, S., Nourbakhsh, M., Irizarry, J., Ressang, A. \& Gheisari, M., Environmental impacts assessment on construction sites. Construction Research Congress 2012, pp. 1750-1759, 2012. DOI: 10.1061/9780784412329.176. 
[19] Chang, Y., Ries, R.J. \& Wang, Y., The quantification of the embodied impacts of construction projects on energy, environment, and society based on I-O LCA. Energy Policy, 39(10), pp. 6321-6330, 2011.

[20] Lippiatt, B.C., Selecting cost-effective green building products: BEES approach. Journal of Construction Engineering and Management, 125(6), pp. 448-455, 1999.

[21] Gangolells, M., Casals, M., Gassó, S., Forcada, N., Roca, X. \& Fuertes, A., Assessing concerns of interested parties when predicting the significance of environmental impacts related to the construction process of residential buildings. Building and Environment, 46, pp. 1023-1037, 2011.

[22] Bernardi, E., Carlucci, S., Cornaro, C. \& Bohne, R.A., An analysis of the most adopted rating systems for assessing the environmental impact of buildings. Sustainability, 9(7), p. 1226, 2017. DOI: 10.3390/su9071226.

[23] Poveda, C.A. \& Lipsett, M.G., A review of sustainability assessment and sustainability/environmental rating systems and credit weighting tools. Journal of Sustainable Development, 4(6), pp. 36-55. DOI: 10.5539/jsd.v4n6p36.

[24] Crawley, D. \& Aho, I., Building environmental assessment methods applications and development trends. Building Research \& Information, 27(4-5), pp. 300-308, 1999. DOI: $10.1080 / 096132199369417$.

[25] Todd, J.A. Crawley, D., Geissler, S. \& Lindsey, G., Comparative assessment of environmental performance tools and the role of the green building challenge. Building Research \& Information, 29(5), pp. 324-335, 2001. DOI: $10.1080 / 09613210110064268$.

[26] Mora-Barrantes, J.C. et al., International Journal of Environmental Impacts, 1(4), pp. 433-449, 2018.

[27] Sanchez, E.T. \& Enriquez, S., Draft: A comparative analysis of environmental impact analysis systems in Latin America, 2007. www.ifc.org/wps/wcm/connect/c688c7004c08ac00ae87be79803d5464/2_EIA+in+L AC+IAIA+Seoul.pdf?MOD=AJPERES. Accessed on: Sep. 2016.

[28] Netherlands Commission for Environmental Assessment, Costa Rica: History of EIA, 2011. www.eia.nl/en/countries/ca/costa+rica/. Accessed on: Sep. 2016.

[29] Ministerio de Ambiente y Energia, Secretaria Tecnica Nacional Ambiental. Documento de Evaluacion Ambiental D-1, 2005. www.setena.go.cr/formulariosd1d2/. Accessed on: Sep. 2016.

[30] Zolfagharian, S., Nourbakhsh, M., Irizarry, J., Ressang, A. \& Gheisari, M., Environmental Impacts Assessment on Construction Sites. Construction Research Congress 2012, 2012. DOI: 10.1061/9780784412329.176. 